\title{
RESEARCH ON FOREIGN INVESTORS NEEDS FOR NEW WORKFORCE IN FREE INVESTMENT ZONES IN AUTONOMOUS PROVINCE OF VOJVODINA
}

\author{
Jelena Damnjanović* \\ Novi Sad School of Business \\ Novi Sad, Republic of Serbia \\ Biljana Stankov \\ Novi Sad School of Business \\ Novi Sad, Republic of Serbia \\ Milijana Roganović \\ Novi Sad School of Business \\ Novi Sad, Republic of Serbia
}

\begin{abstract}
As one of the most economically and culturally developed regions in the Republic of Serbia, since the beginning of the XXI century the Autonomous Province of Vojvodina (AP Vojvodina) has been a particularly attractive investment destination. Therefore, the research of the potentials and the incentives that this location is offering was very interesting for the authors of this empirical study. The subject of this research is about the identification of the needs of the foreign investors for the new workforce. The sample of the research included 18 companies owned by foregin investors that operate in the free investment zones in AP Vojvodina (Novi Sad, Zrenjanin, Subotica and Apatin). Apart from attracting foreign investments, one of the fundamental reasons for creating free investment zones in the Republic of Serbia and AP Vojvodina was the increase of employment. Therefore, the goal of this research is the analysis of foreign investors' experiences with the jobs that were highly wanted during the research period, as well as identifying the key skills of the workers that are deemed the most important for the aforementioned jobs. With this empirical research the authors are confirming the general and specific research hypothesis and conclude that the foreign investors that have been operating in the free investment zones of the AP Vojvodina in 2018. have increased the level of employment in this region because they employed new workers with specific qualifications. Their needs for specific job positions were well-defined and clearly oriented towards several most sought-after jobs, while the certain worker skills were identified as key points for working on the newly-opened job positions.
\end{abstract}

\footnotetext{
*jdamnjanovic5@gmail.com
} 
48 I RESEARCH ON FOREIGN INVESTORS NEEDS FOR NEW WORKFORCE IN FREE INVESTMENT ZONES IN AUTONOMOUS PROVINCE OF VOJVODINA

Keywords: foreign investors, free investment zones, workforce, worker skills, AP Vojvodina

JEL classification: F21, E22, E24

\section{ISTRAŽIVANJE POTREBA STRANIH INVESTITORA ZA NOVOM RADNOM SNAGOM U SLOBODNIM INVESTICIONIM ZONAMA AUTONOMNE POKRAJINE VOJVODINE}

Sažetak: Kao jedan od privredno i kulturno najrazvijenijih regiona u Republici Srbiji, AP Vojvodina je od početka XXI veka pa nadalje, bila posebno privlačna investiciona destinacija, te je istraživanje potencijala i podsticaja koje ova lokacija nudi bilo posebno izazovno za autore ove empirijske studije. Predmet istraživanja se odnosi na identifikovanje potreba stranih investitora za novom radnom snagom, a istraživačkim uzorkom je obuhvaćeno 18 kompanija u vlasništvu stranih investitora koje posluju u slobodnim investicionim zonama u AP Vojvodini (Novi Sad, Zrenjanin, Subotica $i$ Apatin). Pored privlačenja stranih investicija jedan od osnovih razloga osnivanja slobodnih zona u Republici Srbiji $i$ AP Vojvodini bio je $i$ povećanje zaposlenosti. Shodno tome, cilj istraživanja jeste analiza dosadašnjih iskustava stranih investitora $u$ vezi sa zanimanjima za kojima je postojala najveća potreba tokom istraživanog perioda, kao $i$ identifikovanje ključnih veština radnika koje se povezuju sa pomenutim zanimanjima i smatraju najpotrebnijim. Sprovođenjem empirijskog istraživanja autori potvrđuju opštu i posebne istraživačke hipoteze i zaključuju da su strani investitori koji posluju u slobodnim investicionim zonama AP Vojvodine tokom 2018. godine povećali nivo zaposlenosti u ovom regionu pošto su angažovali nove radnike određenih kvalifikacija. Njihove potrebe za pojedinim zanimanjima su bile tačno određene i jasno orijentisane ka nekoliko najtraženijih zanimanja, a odgovarajuće veštine radnika su identifikovane kao ključne za obavljanje poslovnih aktivnosti na novootvorenim radnim mestima.

Ključne reči: strani investitori, slobodne investicione zone, radna snaga, veštine radnika, AP Vojvodina

\section{INTRODUCTION}

As one of the most developed regions in the Republic of Serbia, since the beginning of the XXI century the Autonomous Province of Vojvodina (AP Vojvodina) has been a particularly attractive investment destination. Therefore, the research of the potential and the incentives that this location is offering was very interesting for the authors of this empirical study. This research deals with the significance of Foreing Direct Investments (FDI) on the economic development of AP Vojvodina, as well as the key characteristics of free 
investment zones and the opportunities that they give the economic entities that are working on their territories. The subject of the research is especially oriented towards foreign investors who are working in the free investment zones on the territory of AP Vojvodina. The free investment zones are geographically limited to the areas in the country that are being independently governed. They are created to attract domestic investments and FDI, to stimulate trade, employment and industry development through different incentives. The incentives are usually for the customs-free imports, simplifying customs procedures, giving tax discounts and subventions, providing infrastructure stimulus etc. Free investment zones influence the stimulation of FDI inflows, foreign currency influx, technology transfer, as well as the employment of local workers and the knowledge overflow that can often be the catalyst for the development of domestic production. They are a very useful tool for stimulating economic growth, the increase of industry competitiveness and attracting foreign investors. The goal of the research within this empirical study is the analysis of the needs of foreign investors, who are doing business in the free investment zones of AP Vojvodina, for the new workforce. Moreover, the goal is the econometric research of certain characteristics of newly employed workers which are deemed as the most needed for the job activities. In the Republic of Serbia there are 14 active free investment zones of which 4 are situated on the territory of AP Vojvodina. Free zones of Novi Sad, Zrenjanin, Subotica and Apatin are physically defined territories of AP Vojvodina, that are equipped with infrastructure and where the economic entities can work on production and service activities with certain stimulative benefits. Apart from attracting foreign investors, one of the key reasons for creating free investment zones was the increase of employment.

The motives for doing this research come from the importance of FDI for the economic growth of AP Vojvodina, since it has to do with the influx of fresh capital from the foreign countries, as well as because of the need for attracting new investors in this region. The authors were also motivated to discover if the current foreign investors are content with the offer on the labor market as well as the characteristics of the employed and available workforce.

In order to gather research data a questionnaire was created and was sent to the participants by mail and email. In processing data, the authors are using descriptive statistical analysis and econometric method of analysis of variance (ANOVA) with the previous usage of F-test and t-test. The authors want to get the relevant conclusions based on the results of the research and to define the recommendations for planning the steps for active employment politics that would contribute to the state of labor market, especially in terms of the decrease of the gap between needed and available qualified workers on the territory of 
50 | RESEARCH ON FOREIGN INVESTORS NEEDS FOR NEW WORKFORCE IN FREE INVESTMENT ZONES IN AUTONOMOUS PROVINCE OF VOJVODINA

AP Vojvodina, with the special emphasis on the required worker skills. Furthermore, it is expected that the results of this research will serve as the quality base in future researches not only of the authors but of the other similar empirical studies as well.

\section{THEORETICAL BACKGROUND}

Setting the theoretical basis for the research will be done through the methods of analysis and synthesis, as well as the methods of induction and deduction. Starting with the individual assumptions through the methods of abstraction and generalization will bring important conclusions for understanding the problem of this research. The methods of description and comparison will be applied in order to compare the alternative stances that can be found in the professional and scientific literature. The method of the compilation will be used in reviewing the available literature and analyzing the results of the research of other empirical studies. In order to create a quality theoretical basis for the research, apart from the aforementioned methods of research, these methods will also be used: method of concretization, specialization, inductive and deductive methods, historical method and the content analysis.

\subsection{FREEE INVESTMENT ZONES AND STIMULATING FDI INFLOWS}

Free investment zones are defined as territorially defined zones that are governed by the specialized body whose job is to provide the incentives to the companies that are physically situated in and also working in the investment zone. First and foremost, the incentives have to do with the customs free import, simplifying customs procedures, tax reliefs, subventions, infrastructure incentives etc. The first modern free zones were created in Ireland in 1959. as "Shannon Free Zone". Today, they exist in more than 130 countries in the world (Cheesman, 2012). The last available data show that the number of free zones in the world continues to grow and that to-date there are over 4.500 free zones around the world (Economist, 2015). However, the largest number of free zones are situated in developing countries. Among the characteristics of free investment zones are the following: they are the geographically defined area that is physically separated, they have singular government and administration, they are offering different benefits for investors who are doing business there and they represent the separate customs area with different customs-free benefits and in which area the simplified procedures are used (Farole, 2011).

Free zones influence the encouragement of the FDI inflows, the increase of foreign currency influx, transfer of new technology, and the employment of local workers and the knowledge spillover especially when it comes to management skills. According to the experts of the World Bank the benefits of 
the free zones can be divided into direct and indirect. Direct benefits are the influx of foreign currency, FDI inflows, government revenues and the import growth, while the indirect benefits are the advancement of the skills of the local workforce, the expansion of economic reforms and the increase of the efficiency of domestic companies.

During the second half of XX century, there was a significant export growth of industrial products. At the end of the ' $50 \mathrm{~s}$, the industrial products started to take the first place in the production structure of the international trade and manage, for the first time, to suppress primary products. Since the ' $60 \mathrm{~s}$ the industrial plants have been moved from developed countries to the developing countries which represents the chance for foreign investors. Free zones enabled the developing countries to attract investments of big companies and to become important exporters of industrial products. The positive influence of free investment zones can be viewed in two ways: apart from the benefit to the country where they are being created, they provide numerous benefits for the companies that do business in their areas.

\subsection{AUTNOMOUS PROVINCE OF VOJVODINA AS THE INVESTMENT DESTINATION}

The majority of regions in Eastern Europe have a very favorable logistic position and offer numerous financial and fiscal benefits with the goal of attracting foreign investors. However, the region of Vojvodina, apart from the aforementioned, offers additional benefits. AP Vojvodina is the crossroads of Paneuropean corridors $\mathrm{X}$ and VII, the tradition and culture of Roman, Byzantine, Turkish and Austro-Hungarian Empire. Moreover, it is characterized by a well-developed network of infrastructure, compared to other regions in Eastern Europe, as well as the good relationship between the productiveness and the qualification of the workforce on the one hand, and the height of wages on the other hand. About 25\% of the population of Serbia is concentrated in this region. As workers, they are usually very qualified and often highly educated.

AP Vojvodina is seen as economically and culturally the most developed region in Serbia that has a very beneficial geographical location, because it borders EU countries, that is, Hungary, Romania and Croatia. Since 2003, the highest number of greenfield projects done on the territory of Serbia originated as the result of activities of foreign direct investors, precisely in Vojvodina. After Novi Sad, Zrenjanin is the leading investment location in this region.

In the Republic of Serbia there are 14 active free zones, with 4 zones located on the territory of AP Vojvodina. Free zones of Novi Sad, Zrenjanin, Subotica and Apatin are physically defined territories of AP Vojvodina, that are equipped 
52 | RESEARCH ON FOREIGN INVESTORS NEEDS FOR NEW WORKFORCE IN FREE INVESTMENT ZONES IN AUTONOMOUS PROVINCE OF VOJVODINA

with infrastructure and where the economic entities can work on production and service activities with certain stimulative benefits. Foreign investors have at their disposition qualified and professional workforce, and they can get basic benefits through very favorable work wages and worker's productivity ratio. Right now, AP Vojvodina is the host of a large number of foreign investors who recognized this region as the attractive investment destination where they also got the needed support and stimulus for the successful realization of their investment projects. According to the data of Vojvodina Development Agency the most attractive economic sectors for foreign investors in this region are: automotive supply industry, agriculture, IT industry and renewable energy. Most investment projects have been done within the mentioned sectors. Those are also the areas that, through the usage of incentive methods, work on attracting new investors. Apart from attracting foreign investors, one of the key reasons for the creation of free zones in Serbia and AP Vojvodina was the increase of employment. Therefore, the authors of this empirical study are working on the needs of foreign investors for new workforce, the most soughtafter jobs and worker skills that the foreign investors deemed the most important for working on newly-opened job positions.

\subsection{WORKFORCE AS ON OF THE DETERMINANTS OF FDI INFLOWS}

The first FDI determinants study was created during the '50s and ' 60 s. These studies were mostly of qualitative character, because of modest possibilities of making more extensive statistical analysis and the often limited data about the FDI inflows. Schneider and Frey (1985) are the authors of an esteemed empirical study about FDI determinants, whose conclusions are very often cited in the scientific literature. These authors are one of the first to classify the determinants of FDI inflows by dividing them in two groups:

- Political determinants (primarily political instability) and

- Economic determinants (the growth of GDP, inflation, balance of payments, labour costs and workforce skills).

Their research included 54 developing countries and with the analysis of the panel series it was established that during 1976, 1979. and 1980. FDI inflows were positively influenced by political stability, skills of the workforce, the size of the market, low inflation and the low expense of the workforce. It is noticed that even back in the pioneering studies, the skills and the expenses of the workforce stood out as the key elements that influence decision making of a foreign investor about the choice of the investment location.

The efficiency of the labour market, as the pillar of the competitiveness which is used to encourage the efficiency of the national economy, encompasses 
numerous indicators that can influence the increase of the competitiveness of the country hosting foreign investors and, furthermore, to intensify the FDI inflows. The elements of the workforce market are seen as the efficiencyseeking determinants of the FDI inflows. Among them is what is now considered as traditional determinant which significance has often been tested in different empirical studies - the workforce costs shown through the wage height in the host country. The statistical significance and the influence of this variable has been researched by: Agiomirgianakis, Asteriou and Papathoma (2003); Baez (2014); Bevan and Estrin (2004); Bevan and Estrin (2000); Chen and Kwan (2000); Gorbunova, Infante and Smirnova (2012); Holland and Pain (1998); Khacho and Khan (2012); Kinoshita and Campos (2002); Kudaisi (2014); Lansbury, Pain and Smidkova (1996); Nishat and Aqeel (2004); Nunes, Oscategui and Peschiera (2006); Popovici and Calin (2012); Pravakar (2006); Ranjan and Agarwal (2011); Sakali (2013); Schneider and Frey (1985) and Vijayakumar, Sridharan and Sekhara Rao (2010)). The aforementioned authors determined in the majority of cases that low wages and the decrease of the total cost of the workforce would encourage FDI inflows, especially when the developing countries are the hosts of foreign investors. Driffield and Taylor (2000) also came to the conclusion that high costs of the workforce are turning away foreign investors from choosing certain investment locations. They think that the choice of the investment location in the CEE region is first and foremost determined by the total costs of the workforce as well as the productiveness of the work. Similarly, Kucera (2002) asserts that the foreign investors favor countries where there are lower standards when we talking about the workforce.

Craigwell (2006) concluded in his empirical study that with the increase of the FDI inflows by $1 \%$ there is an increase of employment by about $3 \%$ as well as the increase of export by almost 9\%, which tells that FDI enables exploit of excess production capacities and the workforce on the host country. Many empirical studies have concluded that the more intense positive effects of FDI on the employment in the host country can be expected when the FDI inflows start coming in the form of greenfield investments. On the other hand, symbolic or even negative effects on the levels of employment in the host country can be expected if the foreign investors are only interested in buying national companies that are in the process of privatization, so the FDI projects are done as mergers and acquisitions (Dicken, 2007).

Through researching the factors that influence making decisions about choosing the investment location, Huggins (2001) concludes that the most important factor is the availability of state subventions and benefits related to the employment of new workers. If the said benefits are not given then most of the foreign investors will not be interested in the potential investment location. In 
54 | RESEARCH ON FOREIGN INVESTORS NEEDS FOR NEW WORKFORCE IN FREE INVESTMENT ZONES IN AUTONOMOUS PROVINCE OF VOJVODINA

the empirical studies the importance of the regulation on the workforce market is rarely tested (Nunnenkamp, 2002), as well as the productiveness of the workforce (Anastassopoulos, 2007; Holland and Pain, 1988) as potential determinants of FDI inflows.

In the econometric research Tanaka (2012) concluded that Japanese companies, that were created through FDI, had more influence on the national employment than the companies that were in the ownership of domestic investors. According to the same author, having in mind the theory of vertical FDI, it is concluded that the low-qualified workers in the developed countries are at the highest risk from their employers who choose to invest in other countries where the wages are on the low level. However, the available studies in scientific literature such as Wagner (2011) emphasize that the coming of the foreign investor has little to no influence on the global employment because they influence only the increase of employment in their own branch office. Moreover, other authors confirm that foreign companies that do business at the location with low wages do not show statistically significant influence, or they show very modest influence on the demand for workforce in the host country (Slaughter, 2000; Konings and Murphy, 2006; Marin, 2006; Harrison, McMillan and Null 2007).

Reviewing scientific and professional literature from the subject area, we can also find empirical studies where the authors emphasize that the foreign investors are not being satisfied only by the low wages at the specific investment location, but what is also very important for them is the existence of social and physical infrastructure within where the workforce has a key role in generating productivity (Thomas, 1996). Furthermore, Kataria and Trabold (2004) conclude that only the combination of low wages and qualified workforce, fiscal and administrative incentives as well as very long traditions in doing certain economic activities stand out a very important elements in choosing a country as the investment location. Szanyi (2003) emphasizes that it is common that an issue of the lack of adequately qualified workforce can arise in the host country.

FDI and workforce, that is, human capital, are connected in a very complex way. While the FDI inflows create possibilities for the spillover of new knowledge to the local workforce, at the same time the level of human capital in the host country is determining the scope of FDI that can be attracted and can influence the ability of the local companies to absorb potential benefits of the spillover effect (Blomstrom \& Kokko, 2003). Aitken and Harrison (1999) state that it is almost always expected from the foreign investors to create new work opportunities for the unemployed. However, it often happens that the newly opened job positions are being filled with workers who are already employed, 
yet who are willing to change their jobs because of the higher wages that the foreign investors can offer them.

\section{EMPIRICAL RESEARCH}

\subsection{DETERMINING THE SIZE AND STRUCTURE OF THE RESEARCH SAMPLE AND DEFINING THE PERIOD OF THE RESEARCH}

The research sample includes foreign investors' companies that do business on the territory of AP Vojvodina within four free investment zones: Novi Sad, Zrenjanin, Subotica and Apatin. According to the data of Free Zones Administration from 2017, 88 users did business in the free zones on the territory of AP Vojvodina, total traffic reached 1381,22 millions of euros, and the number of employees was 11.426. From the total of 88 users, the research sample included only those companies that are owned by the foreign investors, that is, 22 companies.

Table 1

Structure of the research sample and the key data about the free investment zones in AP Vojvodina

\begin{tabular}{|c|c|c|c|c|c|}
\hline $\begin{array}{c}\text { Name of the free } \\
\text { zone }\end{array}$ & SUBOTICA & ZRENJANIN & NOVI SAD & APATIN & Total \\
\hline $\begin{array}{c}\text { Year of } \\
\text { establishment }\end{array}$ & 1996 & 2005 & 2009 & 2014 & - \\
\hline Domestic users & 12 & 5 & 47 & - & 66 \\
\hline Foreign users & $\mathbf{5}$ & $\mathbf{3}$ & $\mathbf{1 2}$ & $\mathbf{2}$ & $\mathbf{2 2}$ \\
\hline $\begin{array}{c}\text { Traffic } \\
\text { (u millions of euros) }\end{array}$ & 852,42 & 224,67 & 275,08 & 29,05 & $1.381,22$ \\
\hline $\begin{array}{c}\text { Number of } \\
\text { employees }\end{array}$ & 4.414 & 4.100 & 2.821 & 91 & 11.426 \\
\hline
\end{tabular}

Note. Free Zones Administration. (2018). Report on business of the free zones in the Republic of Serbia for 2017. Belgrade: Ministry of finance.

The research was done from September to December of 2019. In order to check the available data, all the potential companies were contacted, and then the questionnaires were sent to them through email and mail. The questionnaires were sent to 20 addresses because through the direct check it came to light that, in the meantime, two foreign companies in the free zone of Novi Sad stopped SCHOOL OF BUSINESS, 1/2019, 47-68 
56 | RESEARCH ON FOREIGN INVESTORS NEEDS FOR NEW WORKFORCE IN FREE INVESTMENT ZONES IN AUTONOMOUS PROVINCE OF VOJVODINA

working. By the end of the research period, 18 nearly filled out questionnaires arrived, after which they were empirically processed.

\subsection{METHODS OF COLLECTING AND PROCESSING RESEARCH DATA}

The authors of this empirical study chose the research method for gathering empirical data through written statements given by the examinees. Questionnaire research was used as the most effective tool, because these researches tend to collect valid and reliable estimations based on the experience and statements of the foreign investors as the employers in the free zones of AP Vojvodina. The questionnaire is made up of 19 questions that are divided to five topics: data on the currently employed workforce, the ways of employing new workers in 2018, the difficulties in employing new workers, the need for the new workforce and their characteristics and other information relevant for the research. The questionnaire has closed-type questions, open-end questions, questions with combined answers where the examinee can circle one of the given answers or add their own answer, and questions where the answer is in the form of Likert scale.

For the needs of this empirical study, the processed answers related to the questions about the needs of foreign investors for new workforce, the most sought-after jobs in the previous year and the most desirable skills of the newlyemployed workers. The answers were given in the form of Likert scale, so the descriptive statistical method and the econometric methodology of the analysis of variance were used. It was researched to what extent the certain skills of the new workers were needed for work on those job positions that were the most wanted during the analyzed year. The examinees showed their stance with the scores from 1 to 5 ( 1 - not needed; 2 - needed to a small extent; 3 - moderately needed; 4 - greatly needed; 5 - extremely needed) towards following worker skills:

S1 Theoretical knowledge,

S2 Practical knowledge,

S3 Management of employees and other resources,

S4 Team work,

S5 Work habits,

S6 Emotional control in communication with other people,

S7 Flexibility towards changes in the workplace,

S8 Achieving the goals through different means of communication

S9 Developed emphaty,

S10 Answering the requests of the parties in professional way,

S11 Creativity and innovation,

S12 Work responsibility, 
S13 Cultural values and upbringing (good manners).

By applying the analysis of variance, the authors are testing the null hypothesis that says that the aritmetic means of the observed populations are all equal $\left(\mathrm{H}_{0}\right.$ : $\mu_{1}=\mu_{2}=\mu_{3} ; \mathrm{H}_{1}$ : at least one of the arithmetic means is different). When the null hypothesis is rejected and it is established that at least one of the arithmetic means of the observed populations is different, the authors carry out further testing to determine where the difference lies. For that purpose, the t-test is used and the pairs of the arithmetic means of all observed populations is tested. This method is used to test the null hypothesis that says that the arithmetic means of the two observed populations are equal. In contrast, the alternative hypothesis aims at the difference in the arithmetic means $\left(\mathrm{H}_{0}: \mu_{1}-\mu_{2}=0 ; \mathrm{H}_{1}: \mu_{1}-\mu_{2} \neq 0\right)$. Before applying the t-test it is necessary to do the testing through F-test. That is how the authors are determining if the variances of the two observed populations are equal. The testing of the null hypothesis is done that says that the variances of the two populations are equal, while the alternative hypothesis refers to the difference of the variances $\left(\mathrm{H}_{0}: \sigma_{1}{ }^{2}=\sigma_{2}{ }^{2} ; \mathrm{H}_{1}: \sigma_{1}{ }^{2} \neq \sigma_{2}{ }^{2}\right)$. If the $\mathrm{F}$ test would show that the variances of the two observed populations are different, only then t-test can be performed as well as the testing of the equality of the arithmetic means as was previously described.

Tested data populations refers to the scores of the foreign investors about the most wanted skills of the new workers related to those professions that showed as the most sought-after during the researched year.

\subsection{DEFINING RESEARCH HYPOTHESIS}

Judging by the defined subject and the goal of the research, and in accordance with the chosen econometric methodology, the authors of this empirical study will test the following research hypothesis:

\section{General research hypothesis}

$\mathrm{H}_{0}$ : Foreign investors who operated in the free investment zones in AP Vojvodina increased the level of employment in 2018. because they employed new workers with specific qualifications.

$\mathrm{H}_{1}$ : Foreign investors who operate in the free investment zones in AP Vojvodina during 2018. did not increase the level of employment in this region because they did not employ new workers with specific qualifications.

\section{Specific research hypothesis}


58 | RESEARCH ON FOREIGN INVESTORS NEEDS FOR NEW WORKFORCE IN FREE INVESTMENT ZONES IN AUTONOMOUS PROVINCE OF VOJVODINA

$\mathrm{Ha}_{0}$ : The needs of the foreign investors who operate in the free investment zones in AP Vojvodina are precisely defined and clearly oriented at several most wanted jobs.

$\mathrm{Ha}_{1}$ : The needs of the foreign investors who operate in the free investment zones of AP Vojvodina are not precisely defined and are not clearly oriented at several most wanted jobs.

$\mathrm{Hb}_{0}$ : Foreign investors who operate in the free investment zones of AP Vojvodina see certain worker skills as very important for working at newlyopened jobs.

$\mathrm{Hb}_{1}$ : Foreign investors who operate in the free investment zones of AP Vojvodina do not see certain worker skills as very important for working at newly-opened jobs.

\subsection{DATA ANALYSIS}

Foreign investors who do business in free investment zones in AP Vojvodina stated that during the analyzed year they have the greatest need for the accountants, IT engineers and electrotechnical and computing engineers. 17\% of the examinees checked these jobs as the most wanted. $11 \%$ said that what they needed the most were machine engineers and civil engineers who have certain licenses, then economists (MSc), economic and administrative technicians and warehouse workers. Only $6 \%$ of the foreign investors state that what they needed the most were electrical fitters of the installations and machines. Based on the structure of the demand of the foreign investors for the said jobs, it can be concluded that they mostly needed workers with high education and even certain licenses as the product of the additional specialization.

In this empirical study, the econometric methodology of the analysis of variance is used in order to test the truthfulness of the null hypothesis that talks about the equality of the arithmetic means of several observed populations:

$\mathrm{H}_{0}$ : Average values (arithmetic means) of the scores of the foreign investors who operate in the free investment zones of AP Vojvodina which are talk about 13 researched skills of the new workers are equal.

$\mathrm{H}_{1}$ : At least one of the 13 average values of the scores of the foreign investors who operate in the free investment zones of AP Vojvodina is different when it comes to the researched skills of the new workers.

The results show that $\mathrm{F}$ is bigger than $F$ crit. $(24,60335>1,79618)$, so the null hypothesis of the equality of the arithmetic means of the observed populations is rejected and the alternative hypothesis is accepted. Based on this, it can be concluded that the average values of the scores of 13 researched skills of the 
new workers given by the foreign investors who do business in the free investment zones of AP Vojvodina are not equal, or at least that one of them is different from the rest. In order to discover the origin of the established difference it is important to do the testing through t-test of all the pairs of arithmetic means. Before the usage of t-test, it is important to establish for every pair of the data if the variances of the two populations are equal and then to focus further analysis only on the data pairs where the variances are different. That is when the F-test is used.

Tabela 2

Analysis of variance - ANOVA

\begin{tabular}{lcrcccc}
\hline \multicolumn{1}{c}{$\begin{array}{c}\text { Source of } \\
\text { Variation }\end{array}$} & $\boldsymbol{S S}$ & $\boldsymbol{d} \boldsymbol{f}$ & $\boldsymbol{M S}$ & $\boldsymbol{F}$ & $\boldsymbol{P}$-value & $\boldsymbol{F}$ crit. \\
\hline Between Groups & 219,9829 & 12 & 18,33191 & 24,60335 & $1,92 \mathrm{E}-34$ & 1,79618 \\
Within Groups & 164,6667 & 221 & 0,745098 & & & \\
& & & & & & \\
Total & 384,6496 & 233 & & & & \\
\hline
\end{tabular}

Note. Calculated by the autrhors.

By using F-test it is established that in the case of nine data pairs the null hypothesis on the equality of the variances is rejected and the alternative hypothesis is accepted $\left(\mathrm{H}_{1}: \sigma_{1}{ }^{2} \neq \sigma_{2}{ }^{2}\right)$ with the confidence level of $95 \%$.

Pair of data

(C4:C3)

$(\mathrm{C} 4: \mathrm{C} 8)$

$(\mathrm{C} 4: \mathrm{C} 7)$

(C4:C10)

$(\mathrm{C} 4: \mathrm{C} 12)$

(C5:C3)

(C9:C3)

(C9:C7)

(C13:C3)
Variance 1>Variance2

$1,323529>0,369281$

$1,323529>0,565359$

$1,323529>0,457516$

$1,323529>0,526144$

$1,323529>0,565359$

$0,996732>0,369281$

$1,176471>0,369281$

$1,176471>0,457516$

$0,888889>0,369281$
F $>$ F Critical one-tail

$3,5840708>2,2718929$

$2,3410405>2,2718929$

$2,8928571>2,2718929$

$2,515528>2,2718929$

$2,3410405>2,2718929$

$2,699115>2,2718929$

$3,1858407>2,2718929$

$2,5714286>2,2718929$

$2,4070796>2,2718929$

After that, the statistical significance between the said pairs of data is still tested with t-test. It is determined that in the case of two pairs of data $\mathrm{C} 4$ and $\mathrm{C} 10, \mathrm{C} 4$ and $\mathrm{C} 12$ the null hypothesis of the equality of the arithmetic means of the observed populations is accepted $\left(\mathrm{H}_{0}: \mu_{1}-\mu_{2}=0\right)$ with the confidence level of $95 \%$, meaning they are eliminated from further analysis. 
60 | RESEARCH ON FOREIGN INVESTORS NEEDS FOR NEW WORKFORCE IN FREE INVESTMENT ZONES IN AUTONOMOUS PROVINCE OF VOJVODINA

Table 3

Descriptive statistics

\begin{tabular}{|c|c|c|c|c|c|c|c|c|c|c|c|c|c|}
\hline & $\underset{\Xi}{\Xi}$ & 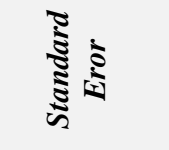 & 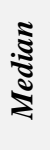 & $\frac{\mathfrak{\Xi}}{\mathbf{z}}$ & 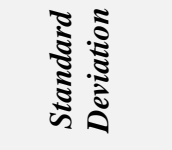 & 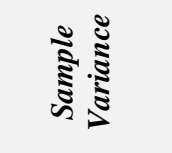 & 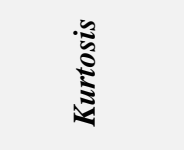 & 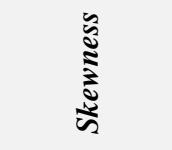 & : & 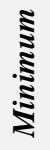 & 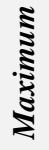 & $\stackrel{\Xi}{\Xi}$ & 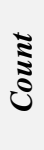 \\
\hline C1 & 3,16666667 & 0,18523964 & 3 & 3 & 0,78590525 & 0,61764706 & $-1,24126984$ & $-0,31810451$ & 2 & 2 & 4 & 57 & 18 \\
\hline C2 & 4,27777778 & 0,19479427 & 5 & 5 & 0,82644209 & 0,68300654 & $-1,25115268$ & $-0,59342406$ & 2 & 3 & 5 & 77 & 18 \\
\hline C3 & 1,38888889 & 0,14323273 & 1 & 1 & 0,60768499 & 0,36928105 & 1,12632156 & 1,36161604 & 2 & 1 & 3 & 25 & 18 \\
\hline $\mathrm{C4}$ & 3,50000000 & 0,27116307 & 3 & 3 & 1,15044748 & 1,32352941 & $-1,40533333$ & 0,13038405 & 3 & 2 & 5 & 63 & 18 \\
\hline C5 & 3,94444444 & 0,23531681 & 4 & 4 & 0,99836468 & 0,99673203 & $-0,37039076$ & $-0,67651616$ & 3 & 2 & 5 & 71 & 18 \\
\hline C6 & 3,33333333 & 0,21389632 & 3 & 3 & 0,90748521 & 0,82352941 & $-0,39897959$ & 0,29516420 & 3 & 2 & 5 & 60 & 18 \\
\hline C7 & 1,88888889 & 0,15942890 & 2 & 2 & 0,67639954 & 0,45751634 & $-0,53081633$ & 0,13200144 & 2 & 1 & 3 & 34 & 18 \\
\hline C8 & 1,72222222 & 0,17722545 & 2 & 1 & 0,75190390 & 0,56535948 & $-0,93346921$ & 0,52852345 & 2 & 1 & 3 & 31 & 18 \\
\hline C9 & 3,66666667 & 0,25565500 & 4 & 3 & 1,08465229 & 1,17647059 & $-1,19000000$ & $-0,17286646$ & 3 & 2 & 5 & 66 & 18 \\
\hline C10 & 4,05555556 & 0,17096845 & 4 & 4 & 0,72535770 & 0,52614379 & $-0,90427067$ & $-0,08562920$ & 2 & 3 & 5 & 73 & 18 \\
\hline C11 & 2,11111111 & 0,19618733 & 2 & 2 & 0,83235236 & 0,69281046 & 0,11165895 & 0,46469797 & 3 & 1 & 4 & 38 & 18 \\
\hline $\mathrm{C12}$ & 4,27777778 & 0,17722545 & 4 & 5 & 0,75190390 & 0,56535948 & $-0,93346921$ & $-0,52852345$ & 2 & 3 & 5 & 77 & 18 \\
\hline C13 & 3,22222222 & 0,22222222 & 3 & 3 & 0,94280904 & 0,88888889 & $-0,38878676$ & 0,45234037 & 3 & 2 & 5 & 58 & 18 \\
\hline
\end{tabular}

Note. Calculated by the authors. 
Table 4

F-Test and t-Test with the confidence level of $95 \%$

\begin{tabular}{|c|c|c|c|c|c|c|c|c|c|c|c|c|c|c|}
\hline \multirow[b]{2}{*}{ 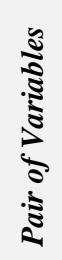 } & \multicolumn{7}{|c|}{ F-Test Two-Sample for Variances } & \multicolumn{7}{|c|}{ t-Test: Two-Sample Assuming Unequal Variances } \\
\hline & 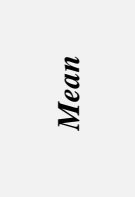 & ב⿱艹 & 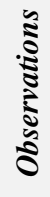 & $\$$ & 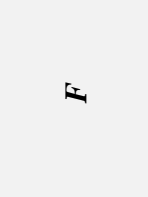 & 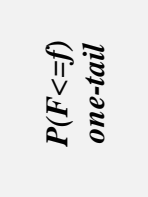 & 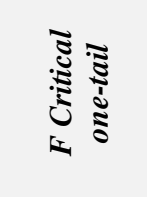 & 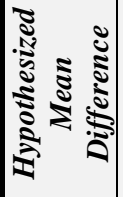 & $\$$ & $\underset{\Xi}{\Xi}$ & 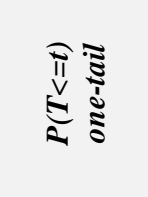 & 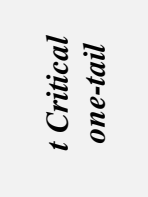 & 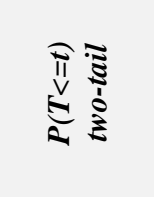 & 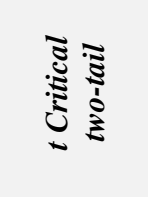 \\
\hline C4 & 3,5 & 1,323529 & 18 & 17 & 3,5840708 & 0,0059751 & 2,2718929 & 0 & 26 & 6,8840367 & $1,311 \mathrm{E}-07$ & 1,7056179 & $2,621 \mathrm{E}-07$ & 2,0555294 \\
\hline C3 & 1,388889 & 0,369281 & 18 & 17 & & & & & & & & & & \\
\hline $\mathbf{C 4}$ & 3,5 & 1,323529 & 18 & 17 & 2,3410405 & 0,0442556 & 2,2718929 & 0 & 29 & 5,4879547 & $3,271 \mathrm{E}-06$ & 1,699127 & $6,542 \mathrm{E}-06$ & 2,0452296 \\
\hline C8 & 1,722222 & 0,565359 & 18 & 17 & & & & & & & & & & \\
\hline $\mathbf{C 4}$ & 3,5 & 1,323529 & 18 & 17 & 2,8928571 & 0,0173904 & 2,2718929 & 0 & 27 & 5,1218188 & $1,098 \mathrm{E}-05$ & 1,7032884 & $2,196 \mathrm{E}-05$ & 2,0518305 \\
\hline C7 & 1,888889 & 0,457516 & 18 & 17 & & & & & & & & & & \\
\hline $\mathrm{C4}$ & 3,5 & 1,323529 & 18 & 17 & 2,515528 & 0,0326823 & 2,2718929 & 0 & 29 & $-1,733070$ & 0,0468531 & 1,699127 & 0,0937061 & 2,0452296 \\
\hline C10 & 4,055556 & 0,526144 & 18 & 17 & & & & & & & & & & \\
\hline $\mathrm{C} 4$ & 3,5 & 1,323529 & 18 & 17 & 2,3410405 & 0,0442556 & 2,2718929 & 0 & 29 & $-2,400980$ & 0,011494 & 1,699127 & 0,0229881 & 2,0452296 \\
\hline $\mathrm{C12}$ & 4,277778 & 0,565359 & 18 & 17 & & & & & & & & & & \\
\hline C5 & 3,944444 & 0,996732 & 18 & 17 & 2,699115 & 0,0239412 & 2,2718929 & 0 & 28 & 9,2767137 & $2,458 \mathrm{E}-10$ & 1,7011309 & $4,915 \mathrm{E}-10$ & 2,0484071 \\
\hline C3 & 1,388889 & 0,369281 & 18 & 17 & & & & & & & & & & \\
\hline C9 & 3,666667 & 1,176471 & 18 & 17 & 3,1858407 & 0,0109087 & 2,2718929 & 0 & 27 & 7,7728045 & $1,166 \mathrm{E}-08$ & 1,7032884 & $2,333 \mathrm{E}-08$ & 2,0518305 \\
\hline $\mathrm{C3}$ & 1,388889 & 0,369281 & 18 & 17 & & & & & & & & & & \\
\hline C9 & 3,666667 & 1,176471 & 18 & 17 & 2,5714286 & 0,029702 & 2,2718929 & 0 & 28 & 5,9005085 & $1,196 \mathrm{E}-06$ & 1,7011309 & 2,393E-06 & 2,0484071 \\
\hline C7 & 1,888889 & 0,457516 & 18 & 17 & & & & & & & & & & \\
\hline C13 & 3,222222 & 0,888889 & 18 & 17 & 2,4070796 & 0,039426 & 2,2718929 & 0 & 29 & 6,9343864 & $6,368 \mathrm{E}-08$ & 1,699127 & $1,274 \mathrm{E}-07$ & 2,0452296 \\
\hline C3 & 1,388889 & 0,369281 & 18 & 17 & & & & & & & & & & \\
\hline
\end{tabular}

Note. Calculated by the authors. 
62 | RESEARCH ON FOREIGN INVESTORS NEEDS FOR NEW WORKFORCE IN FREE INVESTMENT ZONES IN AUTONOMOUS PROVINCE OF VOJVODINA

In the cases of all the other pairs of data the null hypothesis is rejected and the alternative accepted that says that the arithmetic means of the observed populations are different $\left(\mathrm{H}_{1}: \mu_{1}-\mu_{2} \neq 0\right)$ with the confidence level of $95 \%$.

$\begin{array}{lr}\text { Pair of data } & \boldsymbol{t} \text { Stat }>\boldsymbol{t} \text { Critical two-tail } \\ \text { (C4:C3) } & 6,8840367>2,0555294 \\ \text { (C4:C8) } & 5,4879547>2,0452296 \\ \text { (C4:C7) } & 5,1218188>2,0518305 \\ \text { (C5:C3) } & 9,2767137>2,0484071 \\ \text { (C9:C3) } & 7,7728045>2,0518305 \\ \text { (C9:C7) } & 5,9005085>2,0484071 \\ \text { (C13:C3) } & 6,9343864>2,0452296\end{array}$

The results show that the observed differences between the arithmetic means of the populations are statistically significant with the confidence level of $95 \%$ and it can be concluded that the average values of the scores of the foreign investors who do business in the free investment zones of AP Vojvodina are significantly different in the case of the following skills S4 and S3, S4 and S8, S4 and S7, S5 and $\mathrm{S} 3, \mathrm{~S} 9$ and $\mathrm{S} 3, \mathrm{~S} 9$ and $\mathrm{S} 7, \mathrm{~S} 13$ and $\mathrm{S} 3$.

Table 5

t-Test: Two-Sample Assuming Unequal Variances with the confidence level of $99 \%$

\begin{tabular}{lrr}
\hline $\boldsymbol{t}$-Test & Variable C4 & Variable C3 \\
\hline Mean & 3,5 & 1,388888889 \\
Variance & 1,323529412 & 0,369281046 \\
Observations & 18 & 18 \\
Hypothesized Mean Difference & 0 & \\
df & 26 & \\
t Stat & 6,884036707 & \\
P(T<=t) one-tail & $1,31053 \mathrm{E}-07$ & \\
t Critical one-tail & 2,478629824 & \\
$\mathrm{P}(\mathrm{T}<=\mathrm{t})$ two-tail & $2,62105 \mathrm{E}-07$ & \\
$\mathrm{t}$ Critical two-tail & 2,778714533 & \\
\hline
\end{tabular}

Note. Calculated by the authors.

Since the same procedure of testing is done with the confidence level of $99 \%$ only one difference between the arithmetic means of two populations stood out as statistically significant. It pointed to the conclusion that the average values of the scores of the foreign investors who operate in the free investment zones of 
AP Vojvodina are statistically different when it comes to the skills S4 and S3 $(6,8840367>2,778714533)$.

\section{DISCUSSION OF THE RESULTS OF THE RESEARCH}

During 2018 foreign investors that operate in the free investment zones on the territory of AP Vojvodina employed 47 new workers. The professions they needed the most were accountants, IT engineers and electrical and computing engineers. A smaller percentage of examinees answered that what they needed the most were mechanical engineers, civil engineers that have certain licences, the economists (MSc), economic and administrative technicians and warehouse workers. In the case of the majority of new employees, and based on the most wanted jobs, it was important to have higher education and besides that, in certain cases, there was also the need for additional professional specializations.

Foreign investors expected from the new employees to have practical knowledge and work habits to a great extent, to do their job responsibly, and to be professional and well-mannered in working with the parties. The workers were moderately expected to show empathy towards others, to be able to join teamwork, to be able to control their emotions in the communication with others, to behave in accordance with the desirable cultural values and to have needed theoretical knowledge to work on the job activities. The abilities such as creativity and innovation are emphasized to a smaller extent. Foreign investors stated that the skills such as managing employees and other resources, achieving the goals through different means of communication and the flexibility for the changes in the workplace were not necessary or were needed to a very small extent for working on the activities on those job positions where there was the highest need during the analyzed year.

Econometric research showed that, by the confidence level of $99 \%$, just one difference between the arithmetic means of the two populations stands out as statistically significant. Accordingly, the authors conclude that the average values of the scores of the worker skills that were given by the foreign investors who operate in the free investment zones in AP Vojvodina, are statistically significantly different when it comes to the skills S4 and S3 $(6,8840367>2,778714533)$. Statistically important difference of the skill scores, with the confidence level of $99 \%$ is determined in the worker skills related to the management of the employees and other resources and the ability to participate in teamwork. Even $67 \%$ of the surveyed foreign investors believe that the management of employees and other resources is a skill that the new workers do not need to have on the job positions that were the most needed during the analyzed year. Significantly smaller percentage of the foreign investors $(28 \%)$ believe that the said skill is important to a very small extent, and $5 \%$ said that it was moderately important. Judging by the structure of the SCHOOL OF BUSINESS, 1/2019, 47-68 
64 | RESEARCH ON FOREIGN INVESTORS NEEDS FOR NEW WORKFORCE IN FREE INVESTMENT ZONES IN AUTONOMOUS PROVINCE OF VOJVODINA

professions that the foreign investors needed the most, and in accordance with the received empirical results, it can be concluded that, during the researched year, the foreign investors did not have the need to employ executive staff for whom it is specific to also have management skills.

\section{CONCLUSION - SCIENTIFIC AND PRACTICAL CONTRIBUTION OF THE RESEARCH RESULTS}

In the last years, the region of AP Vojvodina has attracted a significant number of foreign investors who attributed to the decrease of unemployment and the acceleration of the economic flows. In the free investment zones of Novi Sad, Zrenjanin, Subotica and Apatin, foreign investors were motivated by the numerous tax and other incentives, as well as the opportunities of employing qualified and professional workers with special benefits. Based on the data of Free Zones Administration of the Republic of Serbia until 2018 the companies that were operating in the free zones of AP Vojvodina had the turnover of 1318,22 million euros with the total of 11426 employed workers. From the total number of companies, $25 \%$ are owned by foreign investors. Reviewing scientific literature it could be concluded that the costs of the workforce and the qualification of workers have always been frequently researched determinants of the FDI inflows. Given the characteristics of the workforce in AP Vojvodina, primarily the qualification and low wages, there is no doubt that it represents one of the key factors that motivates foreign investors to choose precisely these investment locations for their future business.

With this empirical research, the authors affirm general and specific research hypothesis and conclude that the foreign investors who operate in the free investment zones in AP Vojvodina during 2018 increased the level of employment in this region since they employed new workers with specific qualifications. Their needs for certain professions were very specific and clearly oriented towards several most sought-after jobs, while certain worker skills were identified as being the key for job activities on the newly-opened job positions. The scientific contribution of the results of this empirical study can be seen in getting the new knowledge about what the foreign investors in the free investment zones of AP Vojvodina thought on the skills of the newly-employed workers. At the same time, the authors confirmed some of the conclusions of the previous empirical studies that were dealing with the same problem and the subject of research. In this way, the basis for doing future research was established, that would further research the thoughts, experiences and the achieved level of satisfaction of the foreign investors on this territory in terms of employed and potential workers.

The results of this empirical study can also have significant practical implications for the creators of public policies, especially policies of 
encouraging the foreign investment and the employment policy on the territory of AP Vojvodina. Furthermore, it can help different institutions that work with the realization of the programs of professional education and improvement, because it clearly shows which skills and abilities of the workers should be emphasized.

The development of the free investment zones on the territory of AP Vojvodina is necessary to encourage in the future because they play a very important role in attracting FDI, they also represent the generators of the economic growth of this territory and encourage employment.

\section{REFERENCES}

Agiomirgianakis, G. M., Asteriou, D., \& Papathoma, K. (2003). The determinants of foreign direct investment: a panel data study for the OECD countries (Report No. 03/06). London, UK: Department of Economics, City University London.

Aitken, B., \& Harrison, A. (1999). Do domestic firms benefit from direct foreign investment? Evidence from Venezuela. American Economic Review, 89, 605-618.

Anastassopoulos, G. (2007). Countries' International Competitiveness and FDI: an empirical analysis of selected EU Member-Countries and Regions. Journal of Economics and Business, 10(1), 35-52.

Baez, A. (2014). A panel data analysis of FDI and informal labor markets. Research Institute of Applied Economics, 4(1).

Bevan, A., \& Estrin, S. (2004). The determinants of foreign direct investment into European transition economies. Journal of Comparative Economics, 32(4), 775-787.

Bevan, A., Estrin, S., (2000). The determinants of foreign direct investment in transition economies. CEPR discussion paper, No. 2638.

Blomstrom, M., \& Kokko, A. (2003). Human capital and inward FDI. Working Paper, 167 (WORDDOC: CEPR-WP-Jan_2003).

Cheesman, A. (2012). Special Economic Zones \& Development: Geography and Linkages in the Indian EOU Scheme. Development Planning Unit Working Paper 145. London: University College London.

Cheng, L. K., \& Kwan, Y. K. (2000). What are the determinants of the location of foreign direct investment? The Chinese experience. Journal of International Economics, 51(2), 379-400. 
66 | RESEARCH ON FOREIGN INVESTORS NEEDS FOR NEW WORKFORCE IN FREE INVESTMENT ZONES IN AUTONOMOUS PROVINCE OF VOJVODINA

Craigwell, R. (2006). Foreign direct investment and employment in the English and Dutch-speaking Caribbean. Project prepared for ILO, Trinidad and Tobago.

Dicken, P. (2007). Global Shift - Reshaping the Global Economic Map in the 21 st century. London, UK: Sage.

Driffield, N., \& Taylor, K. (2000). FDI and the labour market: a review of the evidence and policy implications. Oxford Review of Economic Policy, 16(3), 90-103.

Economist. (2015). Special economic zones: Not so special. Retrivered from: https://www.economist.com/leaders/2015/04/04/not-so-special

Farole, T. (2011). Special Economic Zones in Africa: Comparing Performance and Learning from Global Experience. Washington, DC: World Bank.

Gorbunova, Y., Infante, D., \& Smirnova, J. (2012). New evidence on FDI determinants: an appraisal over the transition period. Prague Economic Papers, 2, 129-149.

Harrison, A. E., McMillan, M. S., \& Null, C. (2007). US multinational activity abroad and US jobs: substitutes or complements?. Industrial Relations: A Journal of Economy and Society, 46(2), 347-365.

Holland, D., \& Pain, N. (1998). The determinants and impact of foreign direct investment in the transition economies: a panel data analysis. In Convergence or Divergence: Aspirations and Reality in Central and Eastern Europe and Russia (Proceedings from 4th Annual Conference). Centre for Research into East European Business, University of Buckingham.

Huggins, R. (2001). Embedding inward investment through workforce development: experiences in Wales. Environment and Planning $C$ : Government and Policy, 19(6), 833-848.

Kataria, K., \& Trabold, H. (2004). FDI and the skill composition of the workforce: the case of the electronics industry in Hungary. Project 'Industrial Restructuring in the Accession Countries', commissioned by EU DG Employment, Contract No. VC/2003/0367.

Khachoo, A., Q., \& Khan, M., I. (2012). Determinants of FDI inflows to developing countries: a panel data analysis. MPRA - Munich Personal RePEc Archive.

Kinoshita, Y., \& Campos, N., F. (2002). The location determinants of foreign direct investment in transition economies. University of Michigan William Davidson Institute and CERP. 
Konings, J., \& Murphy, A. P. (2006). Do multinational enterprises relocate employment to low-wage regions? Evidence from European multinationals. Review of World Economics, 142(2), 267-286.

Kucera, D. (2002). Core labour standards and foreign direct investment. International Labour Review, 141(1-2), 31-69.

Kudaisi, B. V. (2014). An empirical determination of foreign direct investment in West Africa countries: a panel data analysis. International Journal of Development and Economic Sustainability, 2(2), 19-36.

Lansbury, M., Pain, N., \& Smidkova, K. (1996). Foreign direct investment in Central Europe since 1990: an econometric study. National Institute Economic Review, 104-114.

Marin, D. (2006). A new international division of labor in Europe: Outsourcing and offshoring to Eastern Europe. Journal of the European Economic Association, 4(2-3), 612-622.

Nishat, M., \& Aqeel, A. (2004). The determinants of foreign direct investment in Pakistan. The Pakistan Development Review, 651-664.

Nunes, L. C., Oscátegui Arteta, J., A., \& Peschiera, J. (2006). Determinants of FDI in Latin America. Documentos de Trabajo/Working Papers from Departamento de Economía - Pontificia Universidad Católica del Perú, No 2006/252.

Nunnenkamp, P. (2002). Determinants of FDI in developing countries: has globalization changed the rules of the game?. Kiel Working Paper, No. 1122 .

Popovici, O. C., \& Călin, A., C. (2012a). Competitiveness as Determinant of Foreign Direct Investments in Central and Eastern European Countries. Revista Economica, 1/2012, 658-666.

Pravakar, S., Dash, R. K., \& Nataraj, G. (2010). Infrastructure development and economic growth in China. Institute of Developing Economies Discussion Paper, 261

Ranjan, V., \& Agrawal, G. (2011). FDI Inflow Determinants in BRIC Countries: A Panel Data Analysis. International Business Research, 4(4), 255.

Sakali, C. (2013). Determinants of Foreign Direct Investment (FDI) in Bulgaria: An econometric analysis using panel data. Journal of Economics and Business, 16(1), 73-97. 
68 | RESEARCH ON FOREIGN INVESTORS NEEDS FOR NEW WORKFORCE IN FREE INVESTMENT ZONES IN AUTONOMOUS PROVINCE OF VOJVODINA

Schneider, F., \& Frey, B. (1985). Economic and political determinants of foreign direct investment. World Development, 13(2), 161-175.

Slaughter, M. J. (2000). Production transfer within multinational enterprises and American wages. Journal of international Economics, 50(2), 449-472.

Szanyi, M. (2003). An FDI-based development model for Hungary-new challenges? (No. 141). Institute for World Economics-Centre for Economic and Regional Studies-Hungarian Academy of Sciences.

Tanaka, A. (2012). The effects of FDI on domestic employment and workforce composition. Research Institute of Economy, Trade and Industry (RIETI).

Thomas, D. (1996). Winner or loser in the new Europe? Regional funding, inward investment and prospects for the Welsh economy. European Urban and Regional Studies, 3(3), 225-240.

Uprava za slobodne zone (2018). Izveštaj o poslovanju slobodnih zona $u$ Republici Srbiji za 2017. godinu. Beograd: Ministarstvo finansija

Vijayakumar, N., Sridharan, P., \& Sekhara Rao, K., C. (2010). Determinants of FDI in BRICS Countries: A panel analysis. International Journal of Business Science \& Applied Management, 5(3), 1-13.

Wagner, J. (2011). Offshoring and firm performance: self-selection, effects on performance, or both?. Review of World Economics, 147(2), 217-247.

Note: This paper is a part of the research project "The analysis of foreign investors experiences in free zones related to the labour market in the Autonomous Province of Vojvodina" financed by the Provincial Secretariat for Higher Education and Scientific Research of Autonomous Province of Vojvodina, Republic of Serbia.

Delivered: 23.03.2019. Accepted: 07.02.2020. 